\title{
Dormation
}

Nordic Journal of Art and Research

ISSN: 1893-2479

www.artandresearch.info

\section{Practice as Research in Drama and Theatre: Introducing Narrative Supervision Methodology}

\author{
Heli Aaltonen ${ }^{1}$ and Ellen Foyn Bruun ${ }^{2}$
}

\author{
Norwegian University of Science and Technology
}

\begin{abstract}
For four decades, the Norwegian University of Science and Technology, NTNU Trondheim, has pioneered the field of drama and theatre in higher education in Norway. This article addresses educational, academic and artistic challenges that emerge when practice as research in the arts enters the academic field of humanities. In particular, the article examines narrative supervision methodology at the master's level. The first part of the paper identifies the foundations of the contextual and methodological challenges. The main body of the article explores three discussion topics, each illustrated by case examples of practical-theoretical master's projects. The first example investigates experiential and theoretical borderland tensions; the second addresses onto-epistemic questions; and the third explores the communication of complex narrative construction. Storytelling metaphors are used to advance our emphasis on narrative inquiry as practitioner-researchers and supervisors. The dilemmas outlined are relevant to the Nordic and international community currently navigating this relatively new research area.
\end{abstract}

Keywords: practice as research in the arts, master's programme in drama and theatre studies, narrative methodology, storytelling, supervision, practitioner-researcher.

\section{Introduction}

This article addresses the emergent educational, academic and artistic challenges that come to the fore when practice as research in drama and theatre enters the field of humanities. We locate the foundations of the practice and discuss central topics concerning the supervision of practice as research at the master's level. Our experience as practitioners spans conventional drama and theatre contexts as well as experimental practices, action-based community projects and a range of applied theatre practices (see Aaltonen, 2006, 2011; Bruun, 2012, 2013). We represent a new research

\footnotetext{
${ }^{1}$ Department of Art and Media Studies, Drama and Theatre Studies, Norwegian University of Science and Technology, NTNU, NO-7491 Trondheim. E-mail: heli.aaltonen@ntnu.no.

${ }^{2}$ Department of Art and Media Studies, Drama and Theatre Studies, Norwegian University of Science and Technology, NTNU, NO-7491 Trondheim. E-mail: ellen.bruun@ntnu.no.
} 
community that Biggs and Büchner (2011) call 'practitioner-researchers'. Members of this community are defined as 'individuals who hold practitioner values, but produce research in an academic context' (p. 83). Our contention is that the content of this article has significance for a broad academic-artistic community in the Nordic countries as well as internationally.

Depending on the context, practitioner-researchers use different concepts and refer to practicebased inquiry in different ways. For Borgdorff (2012, p. 13), the concept of 'artistic research' refers to 'research in arts' as opposed to 'research on arts'. His context is professional music education. According to him, artistic research 'is not self-referential at all: it is dynamic chains of interactions, transformations, and articulations that may ultimately produce more reality' (2012, p. 11). Professor of performance art at Theatre Academy Helsinki, Arlander (2011, p. 321) writes that 'practice-based and art-based research frequently has a practical, critical or emancipatory knowledge interest, whereas artistic research seems to find contact points with philosophical research, sharing its speculative freedom'. In our context, the terms most used are 'practice-based' or 'art-based research' for projects focusing on participation and interaction and 'artistic', 'practice-led research' or 'research in arts' when the focus leans towards arts production. In current performance practice, however, practices are interwoven. Each student is required to articulate the specificity of his or her own project and develop an adequate research design. The role of the supervisors, as we will discuss in this article, is to support and guide the journey into this new expanding territory.

Encouraged by Biggs and Karlsson (2011), we have structured the article into three parts: foundations, contexts and voices. In the first part, we locate the lineage of practice as research in drama and theatre studies. In the second part, we describe more closely the context and conditions of the practical-theoretical master's programme at NTNU. Upon introducing the methodology, we disclose the narrative supervision practice in the main body of the article, voices. The first case example, Ingvild Aarseth (2012), presents particular borderland tensions (Clandinin \& Rosiek, 2007, pp. 35-75). These are tensions created in different material-discursive practices based on diverse philosophical frameworks. To demonstrate the implications of such tensions, we explore how lived experience and the narratives of the experience are always negotiable. We then move on to Jorid Bakken Steigum's (2012) case which illustrates the multimodal onto-epistemic approach that guides our narrative thinking. This example clarifies how narrative inquiry supported the student's process as a teacher-artist acquiring new skills and reflective tools. It resonates well with the model of practice as research in the arts presented by Nelson (2013, p. 37). Finally, we present the Pearce Associates' LUUUTT-model of communication (Pearce Associates, 2004, pp. 58-60), which offers a way to open up, be curious and ask questions about different symbolic and material layers of communication. The third case example, Hanne Wiseth (2011), will demonstrate this model which assisted the student to become increasingly aware of her own choices of stories and story construction.

In the conclusion, we reinforce the view that the Drama and Theatre Studies programme at NTNU has a potent role to play and explore in the future. The practical-theoretical legacy is well established from within the academic context in the humanities field. In the Norwegian context, this is especially relevant with regards to third-cycle studies at the $\mathrm{PhD}$ level. The master's programme is currently negotiating the field by exploring and developing new scholarly practice that ensures academic rigour and critical reflection as well as new innovative artistic and arts-based practices. The case examples however illustrate that this is a complex landscape of combined artistic-academic practice. The conclusion points out that narrative inquiry and storytelling devices enhance critical reflection and embodied experiential awareness in arts practice as research. 


\section{Foundations}

We shall now locate the influences and affiliations regarding the practitioner-researcher community at NTNU. The production of knowledge in performance practice is an ontological as well as an epistemological act that is different from ordinary arts practice. Performative research in the arts often requires methods that are applied in vocational training where the focus is to make the tacit and embodied knowledge explicit through the analysis of practices, multimodal discourses and contextual social settings (Kress \& van Leeuwen, 2001). In identifying the field, Arlander writes that '[d]ifferent art forms create different problems for artists starting with research, depending on what dimension of research seems especially alien to ordinary art practice within the field' (2011, pp. 315-332). She points out that different performing arts practices have different traditions in terms of reflection and documentation. For Arlander, the three main themes for practitioner-researchers are to define 'the role of research in artistic practice', 'the position of the artist', and 'the place of the artwork' (pp. 315332). These are all relevant questions for the practical-theoretical master's programme at NTNU. There is often a fourth theme that requires the ethical awareness of the participants' role in the research. In The Conflict in the Faculties: Perspectives on Artistic Research and Academia, Borgdorff (2012, p. 7) asks 'what are the characteristics of artistic research?' He contends that a 'field of action' was established between artistic research and academia in some countries since the early 1990s (Borgdorff, 2012, p. 6). According to him, it is impossible to serve a fixed 'state of affairs' in artistic research because it is rapidly changing and is created in a variety of contextual settings. He further explores a wide range of relevant themes around science, art and politics, onto-epistemic and methodological questions. Moreover, Kershaw (2012, p. 106) makes reference to Gislén's (2006) world map of 'research in the artistic realm'. Finland, Great Britain and Australia are represented on the map with capital letters among the small-lettered Nordic countries (Denmark, Norway and Sweden), the continents and political unions. Gislén's map is a visual representation of the fluid and politically unstable 'state of affairs'.

The situation, however, is rapidly changing. From 2010 to 2013, an ERASMUS network project, Step-Change for Higher Arts Research and Education (SHARE) brought together 35 partner institutions from 28 European countries to internationally map the development of artistic research at the doctoral level (Wilson \& van Ruiten, 2014). In SHARE: Handbook for Artistic Research Education, Elkins (2014, pp. 10-15) identifies six PhD cultures, namely, the 'Continental Model', the 'Nordic Model', the 'UK Model', the 'Japanese Model', the 'Chinese Model' and the 'Lack of a North American Model'. The SHARE (2014) network's internet page is a good starting point for updated information about the moving 'state of affairs' in the field. In Norway, the formal body of artistic research is based at the National Academy of the Arts in Bergen (Norwegian Artistic Research Programme, 2014) with NTNU as one of the partners. It is possible to pursue a practice-based, artistic doctoral study, but this is not yet an accredited $\mathrm{PhD}$ within the academic system.

\section{Contexts}

The Drama and Theatre Studies programme at NTNU is firmly rooted in the conventional humanistic academic research practice. This gives it a pre-eminent location in the field of practice as research in the arts in Norway. The critical reflection exercised in academia offers updated models for disseminating practice-based work. In the context of artistic research, critical reflection and 'making narratives about one's own work' might be challenging, as pointed out by Vassenden (2013, p. 2). There is, however, much to be offered today in the interface of drama and theatre practice as research 
in artistic and applied contexts which accentuates concerns relating to participation, ethics, aesthetics and assessment (e.g. Prendergast \& Saxton, 2009; Thomson \& Sefton-Green, 2011).

The current practice at NTNU and what is taught at the master's level can be traced to three main influences linked to international networks and traditions. The first is the influence from the Nordic countries (Arlander, 2013, pp. 152-163; CARPA, 2009, 2011 and 2013; Friberg, Parekh-Gaihede \& Barton, 2010); the second from Great Britain (Allegue, Jones, \& Kershaw 2009; Kershaw \& Nicholson, 2011; Nelson, 2013; PARIP, 2001-2006; Riley \& Hunter, 2009) and the third from Australia (Smith \& Dean, 2009). Together, these influences represent a rich triangle that identifies the specific foundations of drama and theatre practice within a research community at NTNU. It may seem arbitrary to define research influences based on geographical location, but there are, however, specific regional perspectives, as presented by Nelson and others in Practice as Research in the Arts (Nelson, 2013).

Early influences were research methodology in drama education (e.g. Taylor, 1996), later complemented by artistic research methodology (Hannula, Suoranta \& Vadén, 2005). Haseman's 'Manifesto for performative research' (2006) has been an important guideline for many since it proposes an alternative research paradigm for practice as research in the arts. With the threefold foundation, practice as research has encompassed applied theatre research, arts-based and artistic research (Aune, 2013; Kunstbasert forskning, 2014; Rønning, 2011) as well as practice-led research following Haseman and Mafe (2009; Rasmussen 2012, 2014). The current research and educational practice is a result of the legacy of the Drama and Theatre Studies programme that has emphasised the equal status of theory and practice since it was established in 1974.

Since 2006, master's students can choose a 60-credit theoretical research project (DRA3090 Master's Thesis in Drama and Theatre) or a practical-theoretical research project. The practicaltheoretical project is divided into two parts. First, the students complete the 30 -credit practical study (DRA3191 Project Course, Practical Option); then, usually in the following term, they write a 30credit master's thesis which aims to disseminate the study of research as practice (DRA3192 Master's Thesis, Practical Option). Between the autumn of 2006 and the spring of 2013, twelve students completed the practical-theoretical master's programme. During the same time, 46 students completed the theoretical master's stream. Among the eight new students in the autumn of 2013, seven plan to conduct practice as research projects either as performance, applied theatre projects or community arts projects of different kinds. Over the last few years, the practical-theoretical option has become increasingly attractive.

The diversity of the practical-theoretical master's projects mirrors contemporary drama/theatre and performance practices. We have chosen three projects as cases examples:

1. Devising methods, exploring physical theatre and participatory photography with secondary school pupils in an extra-curricular applied theatre context (Aarseth, 2012; supervisor Heli Aaltonen),

2. An artistic direction of Fosse's (1996) Somebody Will Come, applying and comparing two different approaches to acting and directing with upper secondary school pupils (Steigum, 2012; supervisor Ellen Foyn Bruun),

3. Dramaturgical exploration and embodied-creative adaptation of Medea by Euripides (Wiseth, 2011; supervisor Heli Aaltonen). 
The projects represent a range of methodologies and contexts of practice as research in arts. The three candidates have given us their consent and permission to present their research stories in this context and have verified that the interpretations of their work do not jeopardise their integrity.

\section{Methodology}

Humans are narrative animals. Stories are such an essential part of meaning-making that we usually do not pay attention to how we choose to tell the story or on what grounds these choices are made. Bruner (1986) has a constructivist approach to narratives, and his philosophical thinking supports our supervision didactics. Clandinin and Connelly (2000, p. 121) write that the task of narrative inquirers is to answer the 'questions of meaning, significance, and purpose [...] of who, why, what, how, context, and form'. These questions assist the narrative inquirer to unpack different aspects of sensory experience.

Further, Leavy argues that narrative inquiry is a useful approach in arts-based research practice (2009, pp. 25-55). Practitioner-researchers need to take into consideration how and why they tell their story and to be aware of the consequences of their choices. This is important for the validation and assessment aspects as well as for research ethics (Leavy, 2009, pp. 155-157). We concur with Leavy that narrative research methodology is suitable for negotiating the specific and multi-layered, experientially lived world. Stories are multiple, polyphonic and inter-textual. In her doctoral thesis, actress and script writer Helka-Maria Kinnunen (2008) tells autobiographical stories about the collaborative theatre making process. In all qualitative research, and particularly in the arts, the use of autobiographical material presents opportunities as well as challenges (Ellis \& Bochner, 2000). Kinnunen (2008) calls the result a 'nomadic dramaturgy, which composes connections and tells eclectic truths' (p. 40). This underpins narrative inquiry as enhancing practitioner-researchers' understanding of how they may make sense of and reflect on their fragmentary sensory moments of practice as research.

We also want to draw attention to the concept of language, acknowledging that how we construct language in stories is complex and multi-layered. Influenced by Maurice Merleau-Ponty (1968), philosopher David Abram has an eco-phenomenological view on language. He writes that

[t]he complex interchange that we call 'language' is rooted in the non-verbal exchange always already going on between our own flesh and the flesh of the world. Human languages, then, are informed not only by the evocative shapes and patterns of the more-than-human terrain. Experientially considered, language is no more the special property of the human organism than it is an expression of the animate earth that enfolds us. (Abram, 1996, p. 90)

How to use language, articulate and reflect on experience is a major topic of interest in the dynamic field of practice as research in the arts. Since the 1960s, narrative thinking has been introduced as a useful tool in qualitative research and other contexts that deal with interaction and communication. Today, speech act theory (Austin, 1962), which emphasises the performativity of language and thinking, is well implemented in many cultural and research contexts. In this paradigm, the act of communicating is regarded as autonomous; it does not only refer to something other than itself as a neutral transmitter of meaning. In drama and theatre, the language of mediation is also the art form itself that is constantly exposed to discursive quality paradigms and conventions. In storytelling, in general, humans create 'possible worlds' (Bruner, 2002) where the world is turned upside down and 'recreated' for different purposes and needs. Further, this happens with what Zipes (2004, p. 3) calls the 'utopian tendency of storytelling'. In this respect, there are pitfalls and challenges in practice as research in the arts as in all other storytelling. Stories are value and attitude carriers, and it may be 
tempting to use canonised success story structures even if the research process and outcomes warrant the use of counter structures (Abma, 2003, p. 229).

To sum up, narrative inquiry offers an approach that provides a tool for reflexivity and critical awareness of knowledge formation. From this perspective, the aim of supervision is to encourage the student's process of becoming increasingly aware of his or her own choices of research story construction. We argue, with reference to Baumann (2007), that we live in 'liquid times'. Narrative methodology underpins the notion that no knowledge is created in isolation and that identities are in 'flux'. The aesthetic distancing in storytelling devices during the research and supervision processes enhances the student's reflexive and critical skills. Furthermore, it underscores the supervisor's responsibility to constantly meta-reflect on and critically analyse the existing artistic-academic story construction and context.

\section{Voices}

In this part of the article, the main focus is on the reflection on the master's projects. The first case example investigates experiential and theoretical borderland tensions; the second addresses ontoepistemic questions; the third explores the communication of complex narrative construction. Metaphors are used to support our methodological emphasis on narrative inquiry and storytelling.

\section{Mapping the journey of reflective experience}

Our task as supervisors is to assist students in their exploration of the new and unknown landscape of the practical-theoretical master's project. Boundaries are abstract lines on maps, and they are not necessarily visible in real life. This is particularly so in the dissemination of practice as research in the arts. The supervisor's role might be seen as that of a travel agent. When the supervisor-travel agent initially meets the student-traveller, she asks: 'What kind of experience are you looking for?' They then co-search for different alternatives. The anticipated journey is, however, not the journey itself. During a journey into the unknown, something unexpected will always appear, and the studenttraveller has to take responsibility for his or her own excursion. He or she needs to decide where to go and how to solve practical problems along the way. The experience of the journey is individual. The supervisor can provide maps, but the students need to navigate on their own, keeping reflective logs of their experience and gathering multimodal documentation from their own travels. Often, they will also be captains of a ferry and will need to take care of passengers' safety.

In performance practice as research, it is necessary to critically reflect on the experience and, in one way or another, to gain access to the experience of the participants. Prendergast and Saxton write

[t]he heart of the reflective process is the space it provides to bring into existence a personal relationship with the material. Reflection allows time to consider the moral attitudes, principles, and beliefs that lie beneath actions and to see these in relation to the views, actions and feelings of others. Reflection lets us see how ideas are mediated and how thought is changed when it becomes concretized through action. (2009, p. 203)

Each master's student is required to build a practical project from beginning to end and simultaneously develop the research question. Early in the process, it is important to develop criteria for participation and for the understanding of aesthetics, ethical questions and assessment (Prendergast \& Saxton, 2009, pp. 187-202). It is equally important to be clear about the chosen research methodology to ensure that multiple voices are heard during the practice-based inquiry. In this process, the travel agent-supervisor 
has an obligation to convey to the traveller-student the hidden, often unarticulated subtexts and tensions in the borderland landscape of practice as research in the arts.

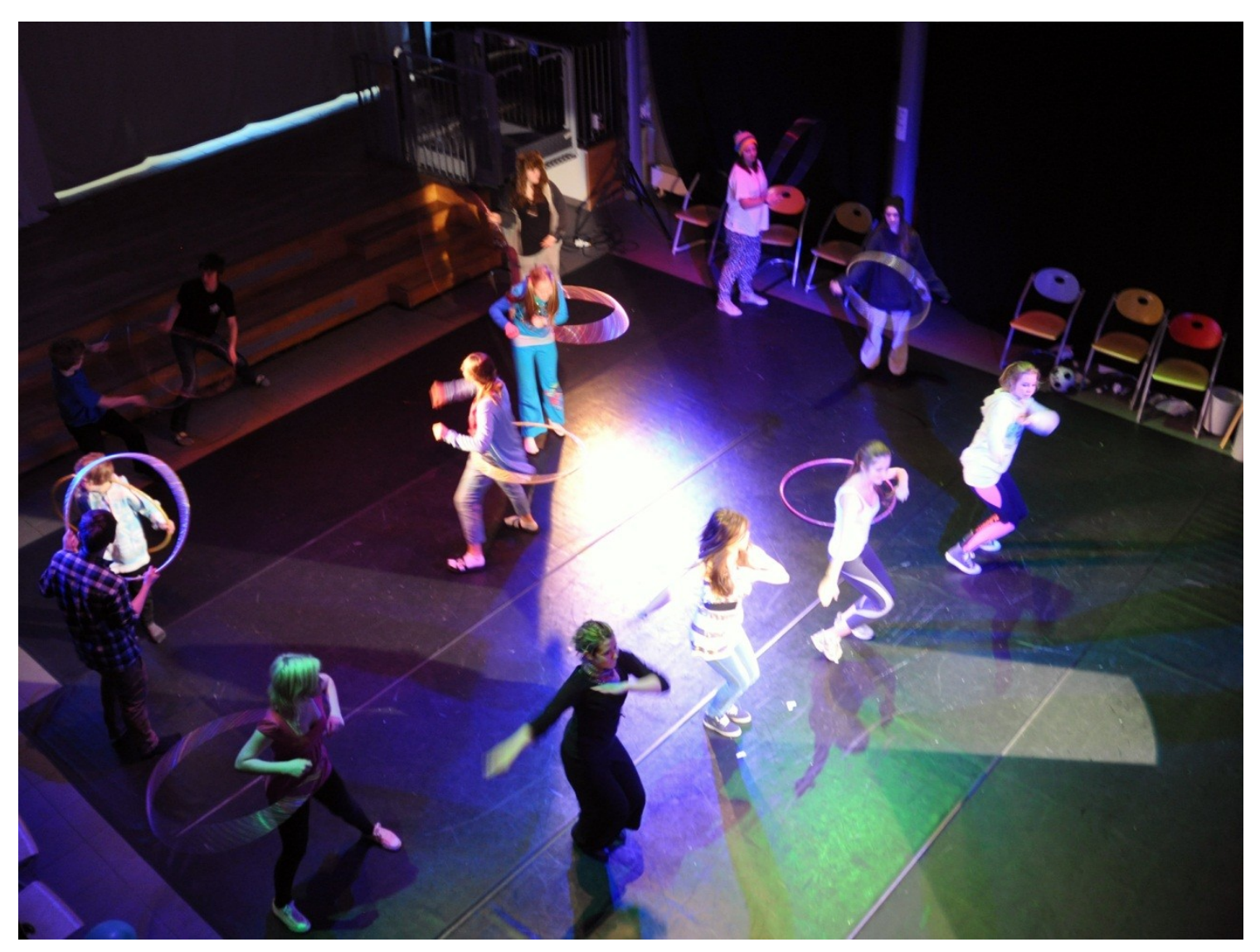

Image 1: Rehearsing Time of Youth. Documentary photography of Aarseth, 2012. Photographer: Simen Hovd.

\section{The first case example}

In the first case, Aarseth (2012) explored physical theatre with secondary school pupils in an extracurricular applied theatre context. She co-devised a play, Time of Youth, with the participants. The stories in the play were based on the pupils' embodied lived experiences. Aarseth was encouraged to use participatory, visual research methods when gathering reflections from the young participants. For this, she used participatory photography, PhotoVoice (Blackman, 2007). In Image 1, she is on stage, in black, rehearsing a dance with the young performers. In the final performance, she performed the role of the dance teacher. With a photographer and the participants, Aarseth divided the photographs (Image 2) into four categories inspired by the concept of 'lifeworld existentials' by van Manen (1990, p. 101). In the project, 'lived space/spatiality' was translated to 'exciting space', 'lived body/corporality' to 'embodied feelings', 'lived time/temporality' to 'magical snapshots' and, finally, 'lived human relation/relationality' to 'relationships'. In addition, Aarseth chose a fifth category 'something else' where she categorised the photographs that did not fit into the other categories. To underpin the importance of the participants' voices in the research project, a photography exhibition was presented to supplement the performance, the main element in Aarseth's practical exam. 


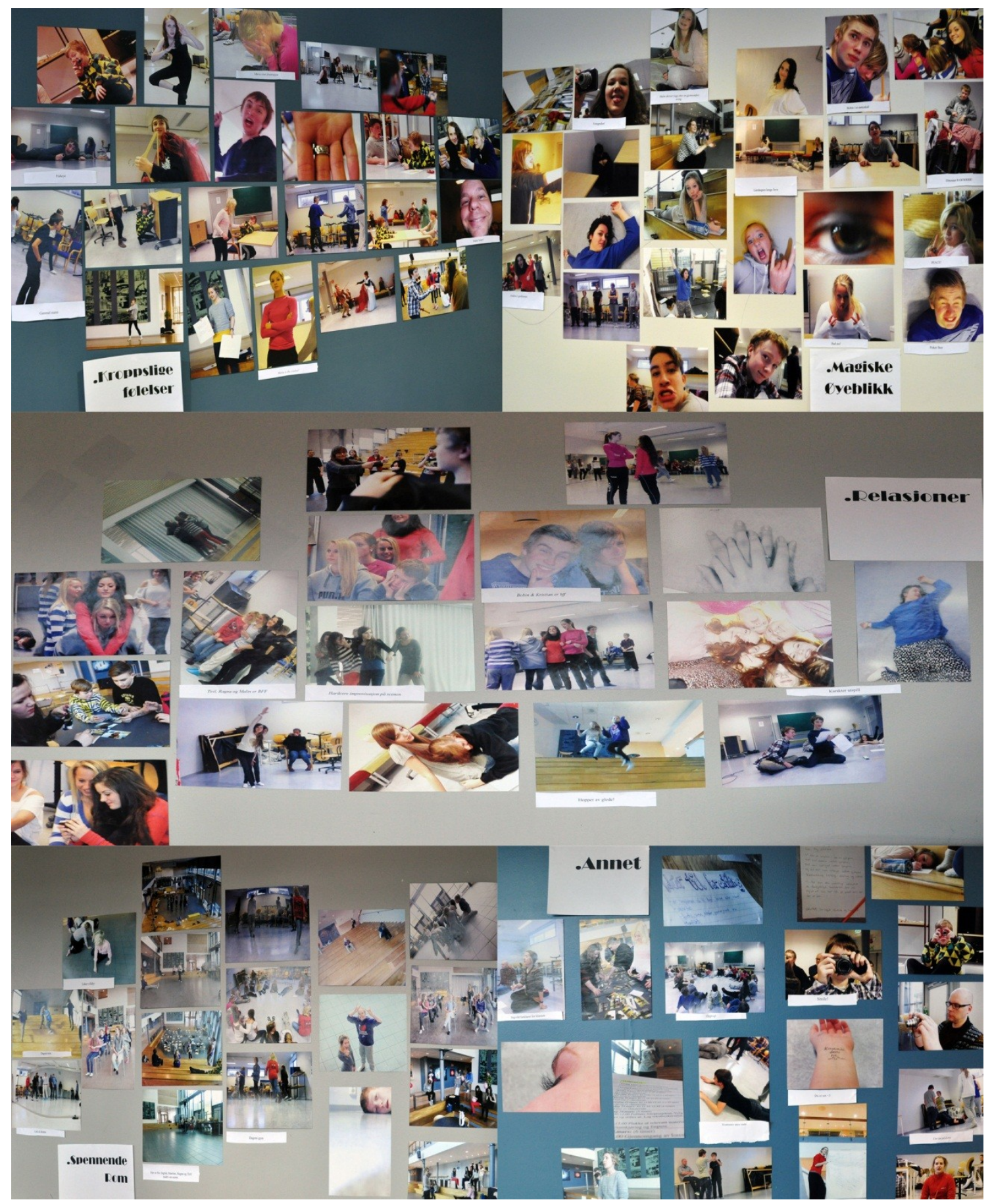

Image 2: Photography exhibition reflecting research participants' experiential journey: at the top left: 'Embodied feelings' (Kroppslige følelser); the top right: 'Magical snapshots' (Magiske øyeblikk); in the middle: 'Relationships' (Relasjoner); the bottom left: 'Exciting space' (Spennende rom) and the bottom right: 'Something else' (Annet). Photographer: Heli Aaltonen.

In Aarseth's case, different discourses of artistic and educational practices met. As she worked with young people in an applied theatre context, this was not surprising. Her research process explored different artistic-pedagogical strategies. During the assessment process of the final performance, the criteria of quality in the arts were tested and laid bare challenges in this kind of practice as research because the performance did not meet the quality criteria of the conventional theatre-goer. Aarseth, herself an experienced dancer, worked with the group of boys and girls on and offstage. The research focus was to investigate how the youngsters could use and develop their creative skills while, at the 
same time, exploring their own identity construction. The show and the photographs conveyed that body and body awareness was an important focus of exploration and new knowledge construction. Some dance scenes showed recognisable, media-dominated choreographies, uncritically performed by the youngsters. These were contrasted by scenes with original and self-invented moves choreographed by the participants themselves. In this way, the performance as a whole demonstrated an aesthetic possibility for the youngsters to explore, non-judgmentally, the known, media-dominated identity construction. Furthermore, it allowed them to find a way to negotiate their own unique expression, constructed in dialogue with the known. In this and similar kinds of artistic applications, it is expected that the aesthetic value and quality of the project might be confronted by normative and conventional elitist criteria.

The responsibility of the supervisor is to provide the students with the necessary tools and sociocultural scaffolding for their learning. When someone crosses disciplinary borders to explore the borderlands between academic, educational and artistic conventions, one needs to be well prepared and diligent. By keeping the focus on and being guided by the research question, the assessment criteria will not pose major difficulties as the logic of the process, and the results will be transparent to the external examiner. Every project needs to be developed in practice through practice as research. While doing this, the tacit know-how of intuitive doing and thinking will be made increasingly explicit, supported by the relevant theoretical and conceptual framework (Nelson, 2013, p. 37). The supervisor's role is to encourage each student to become explorers of the new landscape and to empower them as practitioner-researchers. It is our task to hold the borderland tensions on the institutional level and critically challenge the canonised story structures on this level in order to create foundations for new knowledge production.

\section{What is an elephant? Claiming a multimodal onto-epistemology}

We now want to elaborate on our understanding of narrative inquiry and storytelling. Stories are reused and modified, and they change meaning. Bruner points out that even if life might be perceived as a narrative, it is not (Bruner 2004, p. 691). The story is always created in one way or another. The dynamic onto-epistemic standpoint advocated here is illustrated by the Indian story of 'The Elephant and the Blind Men' (Jainism Global Resource Center, n.d.). When the blind men approach the elephant to find out what it is, they each touch a different part of the animal. The first blind man who touches its leg thinks it is a pillar. The second one who touches its trunk thinks it is a thick branch of a tree or maybe a snake. The third one touching the ear of the elephant thinks it is a big wing. And so they continue until the sixth blind man begins to argue about the nature of the elephant based on his individual experiential knowledge of it. A wise man comes by and makes them understand that they are all telling the story differently because each of them has touched a different part of the elephant. When they understand that they are all right, the fighting ends. The different sensory experiences were all partial truths that could co-exist. The moral of the story is that different narratives of the same reality can coincide in harmony.

Rather than arguing like the blind men, we should ask 'from which perspective do you address the question?' We concur with Arlander (2011, p. 316) who offers illuminating examples of how the work in performing arts 'could be looked at differently depending on the art form'. Equally important are the practical methods and conceptual frameworks chosen for a project. For arts practice as research, the researcher's ability to think reflexively in the context of the whole body-mind is essential. Embodied thinking does not happen as an esoteric, mental concept. It relates to the matter of engaging sensory, feeling and intellectual practices. As such, thinking is regarded as a whole body activity, not 
as something only going on in the mind. Nelson's (2013, p. 37) model of practice as research in the arts offers a representation that resonates with the narrative approach. Nelson advocates a multimodal onto-epistemic model that dynamically negotiates three components in praxis. These are, first, the know-how and 'insider' close-up knowing, then, the know-what where the tacit is made explicit and, finally, the know-that which represents the cognitive 'academic' knowledge with the conceptual frameworks and propositional knowledge (Nelson, 2013, p. 37). In our view, this dynamic model invites the unfolding of complex narratives and narrative construction.

\section{The second case example}

Complex interweaves of lived experiences and narratives are at stake in all learning and research processes. We have witnessed many instances in which students suddenly understand their previous learning and knowledge from a new perspective. The tacit knowing becomes explicit and is understood conceptually on a new level. In our second case, Steigum (2012), an experienced drama teacher, undertook a practice as research project with upper secondary drama pupils as co-researchers. She directed Fosse's (1996) play Somebody Will Come in two versions based on different approaches to acting and directing. On the one hand, she used Bogart and Landau's (2005) physical theatre methods, viewpoints and composition, and on the other hand, she applied a conventional psychophysical acting methodology using the Stanislavsky tradition (Image 3).

Throughout the practice as research, Steigum critically questioned the role of the drama teacher squeezed between pedagogical and artistic expectations and motivations. Her work was aimed at contextualizing this experienced reality and strengthening the artistic dimension of the drama teacher. In the theoretical dissemination, she analysed and discussed the practical project that ended with two different versions of Fosse's play, shown as a double act. When artistic processes claim to create research knowledge, it is crucial that the knowledge production transgresses the individual learning and is of interest to a broader community. The title of Steigum's master's thesis, A Leap in the Dark (2012), was directly inspired by Bogart and Landau (2005). The result was not only of interest to the community of arts educators in upper secondary schools but of general interest to all arts practitioners involved in onto-epistemic dilemmas where arts practice as research is involved. For Steigum, it was an empowering journey towards making the tacit and embodied knowledge increasingly explicit and theoretically framed. The hegemonic narrative of splitting art and education was not changed as such, but Steigum was able to position herself as practitioner-researcher claiming her agency and artistic integrity in relation to the context and given circumstances. One could say that she crossed boundaries and created a counter narrative about being a drama teacher. In short, she conquered new territory by seeing through the power structures, understanding the nature of the borderland tensions. In a telephone conversation dated January 25, 2014, she summed up that 'the leap in the dark had become a leap into the light'. 


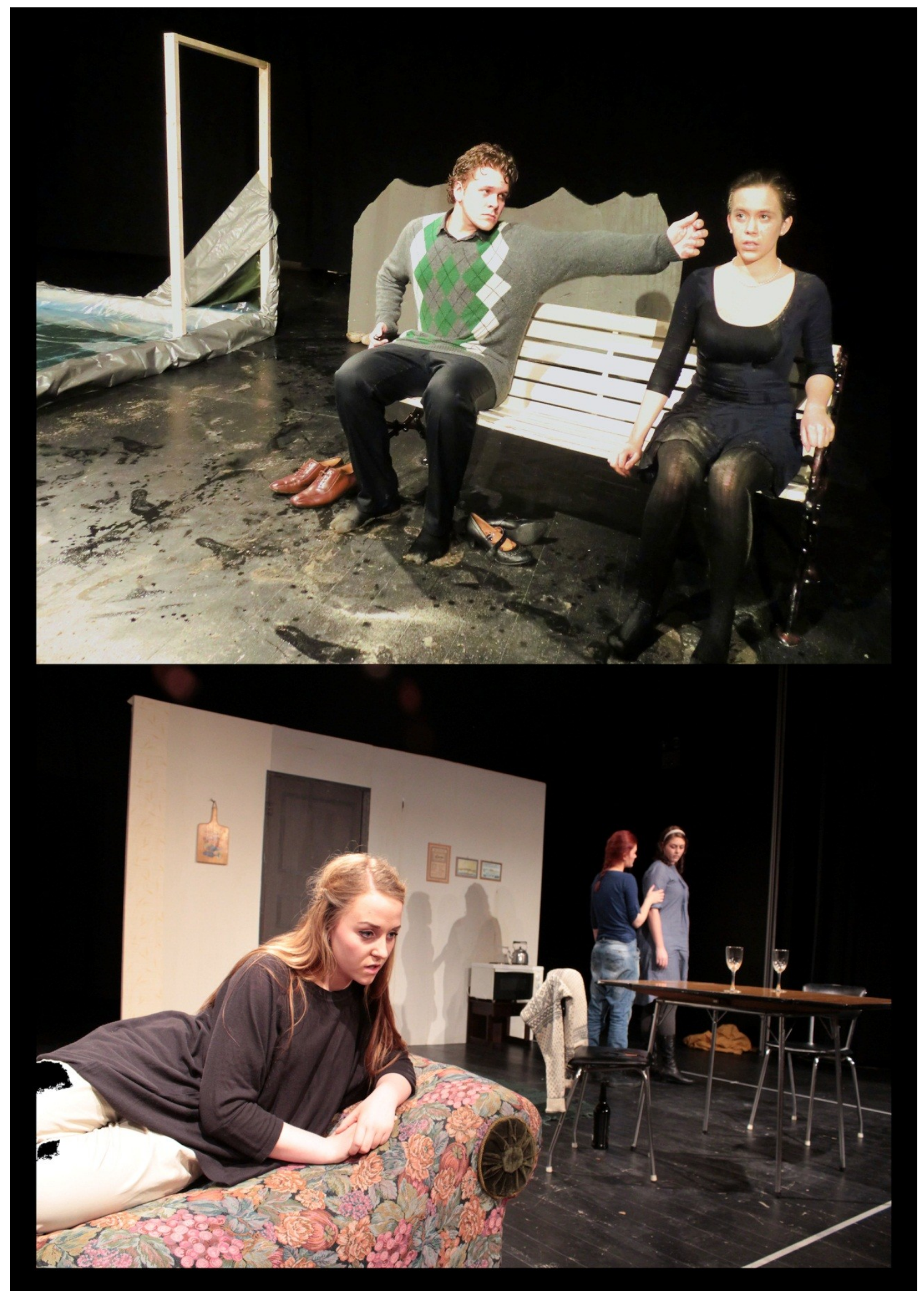

Image 3: Visual documentation of Steigum's staging of Somebody Will Come by Jon Fosse.

The photograph above is from the Bogart-inspired version; the photograph below is from the Stanislavsky-inspired version. Photographer: Jorid Bakken Steigum. 
Supported by systematic research documentation of audience experiences and the pupils' learning outcomes, Steigum's project enabled her to identify her own research contribution. She was empowered as an artist-teacher who gained new insight into arts practice as research. The research outcome included a critical-constructive lens on arts education in Norwegian higher education. In this way, as a case study, Steigum's research narrative offers inspiration to others. The strength of this kind of qualitative research narrative is that it invites the reader/spectator to become critically creative about his or her own choices of narrative affiliation and inclination through analogy and comparison.

\section{Communicating complex narrative construction}

This takes us to the discussion topic that brings forward perspectives and tools for communicating complex narratives. The LUUUTT-model, originally presented by W. Barnett Pearce in 1999 (2004, pp. 58-60), exemplifies the multiple tensions between different potential and possible stories. It crystallises important aspects of narrative inquiry that is useful in arts practice as research. The components of the LUUUTT-model are: 1. stories Lived, 2. Unknown stories, 3. Untold stories, 4. Unheard stories, 5. stories Told, and 6. storyTelling (Pearce, 2004, p. 58). The model illustrates how the creation and interpretation of narratives depend on the climate of the communication, the contextual setting and the relationship between storyteller and listener. The dynamics of the model might be seen as a 'spiralling evolutionary process' (Pearce, 2004, p. 59) where unheard stories become untold stories, and untold stories become, after a while, unknown stories and vice versa.

The model contributes to a focus on storytelling as an activity in which the narrator assumes responsibility for choosing which story is worth telling. There might be numerous untold, unknown and unheard stories worth telling, hiding somewhere waiting to be discovered. The task of the scholar is to investigate the story that is worth telling. The LUUUTT-model encourages the researcher to connect practice-based research and narrative inquiry in 'iterative and cyclic processes' (Smith \& Dean, 2009, p. 20).

\section{The third case example}

In our third case, Wiseth (2011) executed her solo performance Mission Aquila for the examination board in the spring of 2011, prior to completing her master's thesis later that year. The starting point for her dramaturgical adaptation project was a real case of child murder in Trondheim and the Greek tragedy Medea by Euripides. Wiseth was interested in working with dramaturgy and in creating a new stage text based on the classical text at the same time as it would be in dialogue with the tangible theme of child abuse. StoryTelling "deals with "how" the stories are told, rather than their contents, narrative features, or place in the conversational interchanges' (Pearce, 2004, pp. 58-60). In a practical-theoretical project in drama and theatre, this means that the students have to be able to defend their choice of aesthetics and how they choose to compose the documentation. In Wiseth's case, the documentation included individual and written logs, drawings and photographs. In addition to the actual stage work with the original text and her own texts, this provided research material that enabled her to tell new stories of her process. According to the LUUUTT-model, stories Lived 'are the coconstructed patterns of joint-actions that we and others perform' (Pearce, 2004, pp. 58-60). Which were the Lived stories in Wiseth's case? During the research process, she studied the theme of honour killing, essential in the original play. What did Wiseth know about honour killing, and what would be her response to such realities? 
This and similar questions draw attention to the next aspect of the LUUUTT-model, namely, the Unknown stories, that is, the stories that 'the participants are not (currently) capable of telling' (Pearce, 2004, pp. 58-60). After having addressed different angles, Wiseth chose to focus her further exploration on the Untold and Unheard stories. Untold stories 'are perfectly capable of being told but have chosen not to (...)' and Unheard stories 'although they have been told, have not been heard by some important participants of the situation' (Pearce, 2004, pp. 58-60). Wiseth decided to address the vulnerable situation of the child. What can a child do when adults do not take care of him or her? Wiseth wanted to open the door to the private home and tell a story about domestic violence. She then arrived at the important question: 'Whose perspective do I choose?' At last, she decided to work with a child murderer instead of an adult murderer. In her version, the Argonaut became the 'astronaut' father who never bothered to visit and take care of the child. The mentally unstable mother never answers, and the child performs 'Mission Aquila' (Image 4). Aquila is a star formation that signifies eagle. The vulnerable child becomes the eagle, and her mission is to become visible.

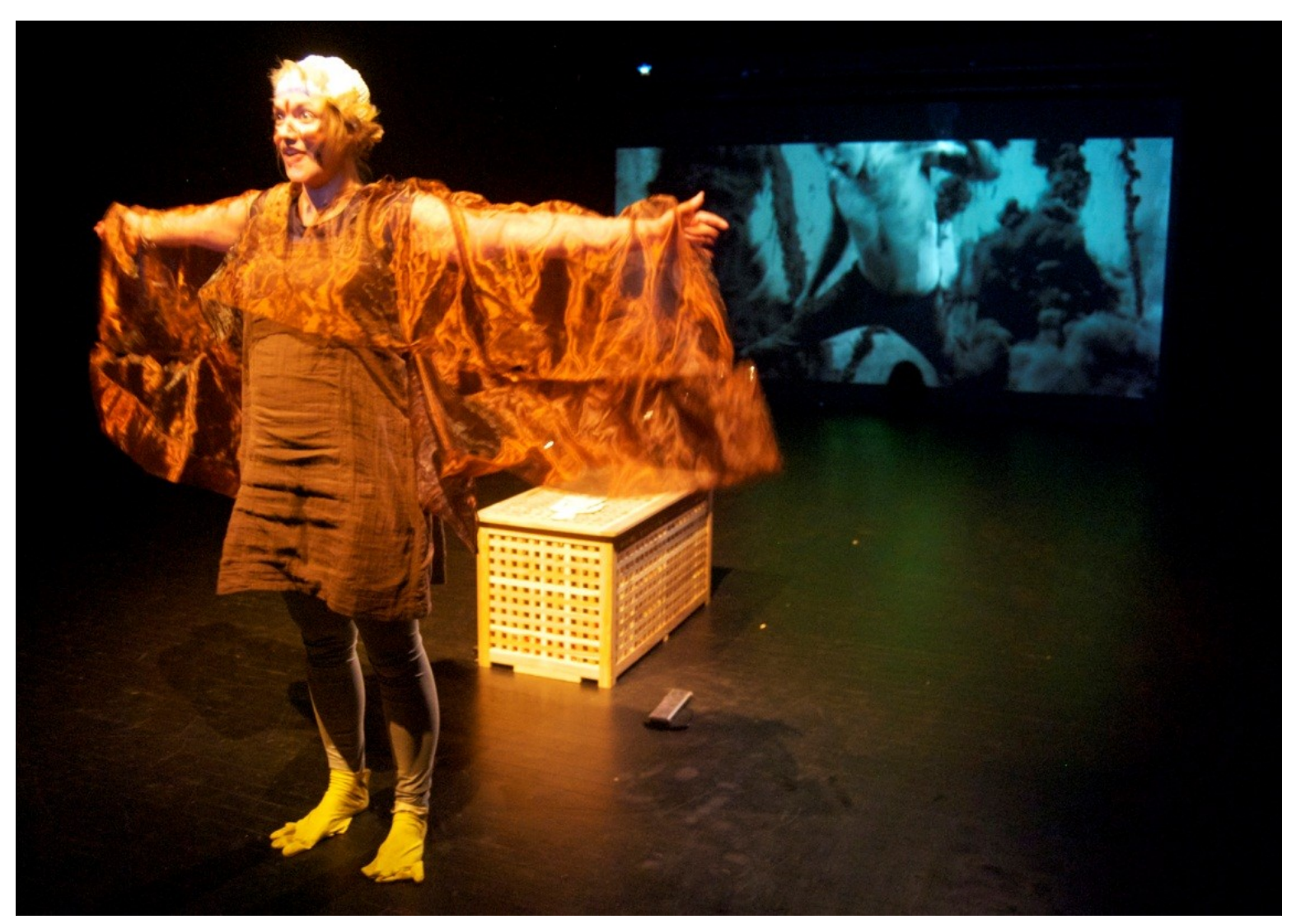

Image 4: Performing Mission Aquila. Visual documentation of Wiseth 2011. Photographer: Magnus Aursand.

In the solo performance, Wiseth played the role of the child protagonist herself. At the end of the performance, the story Told of the mother's death was left open as to whether the child really murdered the mother. The research focus in Wiseth's case was not her acting skills or the staging of the performance. The axis of research addressed the adaptation strategies of turning the original text upside-down and inside-out through the choice to focus on the child, not as a victim but as the aggressor. It was quite a disturbing piece of theatre, as one might also say of Euripides' Medea. Through the complex dramaturgical strategies, the result conveyed relevant aspects of the original 
dramatic text as well as Wiseth's own multi-layered response to it. Through the research process and dissemination, much of the tacit knowledge and knowing as a theatre practitioner was anchored theoretically, and new knowledge was made available to a broader audience.

To sum up, the LUUUTT-model provides a concrete tool for addressing the communication of complex narrative construction. As we have demonstrated with the third case example, it offers the practitioner-researcher multiple perspectives. For Wiseth, it encouraged her to constantly address her own story construction with and from new angles. According to the creators of the model, stories Told 'are explanatory narratives that people use to make sense of stories lived' (Pearce, 2004, pp. 58-60). In any research context, the stories Told need to be challenged. As Vassenden $(2013$, p. 32) points out, critical reflection and the location of practice as research in a conceptual and theoretical universe is decisive for validation. For Wiseth, the LUUUTT-model assisted her as a storyteller-researcher to become increasingly aware of her own choices of stories and story construction.

\section{Conclusion}

In this article, we have reflected on educational, academic and artistic challenges when practice as research in drama and theatre enters the field of humanities. We have argued that narrative inquiry and storytelling are a useful methodological approach in arts practice as research. The combination supports the dynamic and multimodal lens advocated by Nelson (2013). We have presented and discussed three case examples investigating aspects of borderland tensions, onto-epistemic questions and complex narrative construction. The case examples represent the multi-layered and complex emerging research area of practice as research in the arts. We claim that the Drama and Theatre Studies programme at NTNU has a potent role to play in the future. The practical-theoretical legacy is well established from within the academic context in the humanities. This is especially relevant with regard to third-cycle studies at the $\mathrm{PhD}$ level in Norway. The current master's programme is negotiating and developing new scholarly practice that ensures academic rigour and critical reflection as well as innovative artistic and arts-based practice. To sum up, we want to emphasise that a critical reflection of artistic-academic practice is decisive to the prosperous development of this fascinating new research area.

Our lens as practitioner-researchers is multimodal and claims an onto-epistemic standpoint that rejects the dichotomy of artistic and scientific practices. We have argued that narrative inquiry and storytelling devices are useful methodological approaches in this kind of research practice since they emphasise poly-vocal narratives of experience and critical meta-reflection of the story construction itself. As representatives of the new community of practitioner-researchers in the arts, our aim is to contribute to the current academic-artistic discourse taking place in the Nordic countries and internationally. Practice as research in the arts reinforces knowledge production that interacts performatively in socio-cultural life and highlights the requirement to renegotiate the role of academia in the twenty-first century.

\section{On the contributors}

Dr. Heli Aaltonen, Associate Professor of Drama and Theatre Studies, Faculty of Humanities, NTNU, Trondheim. She is a theatre researcher, performing storyteller and theatre/drama educator with a specialisation in applied theatre practices and arts-based research methods. At the moment, she is interested in adapting new materialist and post-humanist perspectives in performance analysis. She is 
interested in undertaking arts-based research projects in a multi-disciplinary field where the environment and performing arts meet.

Ellen Foyn Bruun, Associated Professor of Drama and Theatre Studies, Faculty of Humanities, NTNU Trondheim. After many years as a stage director, dramaturge and drama teacher in Norway and Denmark, she specialised as a drama therapist in London in 2007. Her current work and research focus on learning and growth processes through drama and theatre practice with an emphasis on how the human body-mind works and relates to the world. A main research area is voice work and methods for enhancing inner listening for authentic expression in life and arts practices.

\section{References}

Aaltonen, H. (2006). Intercultural bridges in teenagers' theatrical events: Performing self and constructing cultural identity through a creative drama process (Unpublished doctoral dissertation). Turku: Åbo Academy University. Retrieved April 10, 2014 from https://www.doria.fi/bitstream/handle/10024/4133/TMP.objres.82.pdf?sequence=2

Aaltonen, H. (2011). Golden merganser story promenade: A case study of oral multilingual storytelling strategies, Journal of Arts \& Communities, 3(2), 193-206.

Aarseth, I. (2012) Kroppen på spill: en undersøkelse av hvordan ungdomsskoleelever skaper sin identitet gjennom fysisk teater og fotografi [Body in play: A study about how pupils at secondary school create their identity by physical theatre and photography] (Unpublished master's dissertation). Trondheim: NTNU.

Abma, T. A. (2003). Learning by telling: Storytelling workshops as an organizational learning intervention. Management Learning, 34(2), 221-240.

Abram, D. (1996). The spell of the sensuous: Perception and language in a more-than-human-world. New York: Pantheon Books.

Allegue, L., Jones, S., Kershaw, B., \& Piccini, A. (Eds.) (2009). Practice-as-research in performance and screen. Hampshire: Palgrave Macmillan.

Arlander, A. (2011). Characteristics of visual and performing arts. In M. Biggs \& H. Karlsson (Eds.), The Routledge companion to research in the arts (pp. 315-332). London \& New York: Routledge.

Arlander, A. (2013). Artistic research in a Nordic context. In R. Nelson (Ed.), Practice as research in the arts - Principles, protocols, pedagogies, resistances (pp. 152-162). Hampshire: Palgrave Macmillan. Retrieved February 01, 2014 from http://www.academia.edu/3733910/Artistic Research in a Nordic Context

Aune, V. (2013). Teaterfaget i kulturskolen: kompetanseutfordringer og muligheter. Kulturskolerådet, Nasjonalt fagforum. Retrieved March 30, 2014 from

http://www.kulturskoleradet.no/upload/bruker/dokumenter/Vi_tilbyr/Arrangement/Nasjonalt_fagfo rum/2013 Vigdis_Aunes foredrag.pdf

Austin, J. S. (1962). How to do things with words. New York: Oxford University Press.

Baumann, Z. (2007). Liquid times: Living in an age of uncertainty. Cambridge: Polity Press.

Biggs, M., \& Büchner, D. (2011). Communities, values, conventions and actions. In M. Biggs \& H. Karlsson (Eds.). The Routledge companion to research in the arts (pp. 82-98). London \& New York: Routledge.

Biggs, M., \& Karlsson, H. (Eds.) (2011). The Routledge companion to research in the arts. London \& New York: Routledge.

Blackman, A. (2007). The PhotoVoice manual: A guide to designing and running participatory photography projects. London: PhotoVoice.

Bogart, A., \& Landau, T. (2005). The viewpoints book: A practical guide to viewpoints and composition. New York: Theatre Communications Group.

Borgdorff, H. (2012). The conflict of the faculties: Perspectives on artistic research and academia. (Unpublished doctoral dissertation). Leiden: Leiden University.

Bruner, J. (2004) [1987]. Life as narrative. Social Research, 71(3), 691-710.

Bruner, J. (2002). Making stories: Law, literature, life: New York: Farrar, Straus \& Giroux. 
Bruun, E. F. (2012). Dramatherapy with homeless clients: The necessary theatre. Dramatherapy Official Journal of the British Association of Dramatherapists, 34(3), 139-149.

Bruun, E. F. (2013). Diversity on the Norwegian stage: Whose story is it anyway? Nordic Theatre Studies, 25, 34-45.

CARPA (2009). $1^{\text {st }}$ colloquium on artistic research in performing arts. Theatre Academy, Helsinki, November 19-21, 2009. Retrieved March 25, 2014 from http://www.teak.fi/menu description.asp?menu id=1198

CARPA (2011). $2^{\text {nd }}$ colloquium on artistic research in performing arts. Theatre Academy, Helsinki, January, 13. -15. 2011. Retrieved March 25, 2014 from http://www.teak.fi/carpa2011

CARPA (2013). $3^{\text {rd }}$ colloquium on artistic research in performing arts, Theatre Academy, Helsinki, February 28-March 02, 2013. Retrieved March 25, 2014 from http://www.teak.fi/Tutkimus/carpa

Clandinin, D. J., \& Connelly, F. M. (2000). Narrative inquiry: Experience and story in qualitative research. San Fransisco: Jossey-Bass.

Clandinin, D. J., \& Rosiek, J. (2007). Mapping a landscape of narrative inquiry: Borderland spaces and tensions. In D. J. Clandinin (Ed.) Handbook of narrative inquiry: Mapping a methodology (pp. 35-75). London: SAGE Publications.

DRA3090 Master's Thesis in Drama and Theatre. Course description. Retrieved June 4, 2014 from http://www.ntnu.edu/studies/courses/DRA3090/2013\#tab=omEmnet

DRA3191 Project Course, Practical Option. Course description. Retrieved June 4, 2014 from http://www.ntnu.edu/studies/courses/DRA3191/2013\#tab=omEmnet

DRA3192 Master's Thesis. Practical Option. Course description. Retrieved June 4, 2014 from http://www.ntnu.edu/studies/courses/DRA3192/2013\#tab=omEmnet

Elkins, J. (2013). Six cultures of the PhD. In M. Wilson \& S. van Ruiten (Eds.), SHARE: Handbook for artistic research education (pp. 10-15). Leiden: Leiden University Press. Retrieved April 11, 2014 from http://www.elia-artschools.org/images/products/120/share-handbook-for-artisticresearch-education-high-definition.pdf

Ellis, C., \& Bochner, A. (2000). Auto-ethnography, personal narrative, reflexivity: Researcher as subject. In N. K. Denzin, \& Y. S. Lincoln (Eds.), Handbook of qualitative research (pp. 733-768). Thousand Oaks, CA: SAGE publications.

Fosse, J. (1996). Nokon kjem til å komme [Somebody will come]. Oslo: Det Norske Samlaget.

Friberg, C., Parekh-Gaihede, R., \& Barton, B. (Eds.). (2010). At the intersection between art and research: Practice-based research in the performing arts. Århus: NSU Press.

Gislén, Y. (2006). Research: Notions and complications. In L. Elkjær (Ed.), Re.Searching - Om praksisbasert forskning $i$ scenekunst (pp. 125-140). Copenhagen: NordScen.

Hannula, M., Suoranta, J., \& Vadén, T. (2005). Artistic research - Theories, methods and practices. Helsinki: Academy of Fine Arts.

Haseman, B. (2006). A Manifesto for performative research. Media International Australia, Incorporating Culture and Policy. Theme issue 'Practice-led research', 118, 98-106.

Haseman, B., \& Mafe, D. (2009). Acquiring know-how: Research training for practice-led researchers. In H. Smith \& R. T. Dean (Eds.), Practice-led research, research-led practice in the creative arts (pp. 211-228). Edinburgh: Edinburgh University Press.

Jainism Global Resource Center. (n.d.). Elephant and the blind men. Story 25. Retrieved April 11, 2014 from http://www.jainworld.com/literature/story $25 . h t m$

Kershaw, B. (2012). Practice as research through performance. In H. Smith and R. T. Dean (Eds.), Practice-led research, research-led practice in the creative arts (pp. 104-125). Edinburgh: Edinburgh University Press.

Kershaw, B., \& Nicholson, H. (Eds.) (2011). Research methods in theatre and performance. Edinburgh: Edinburgh University Press.

Kinnunen, H.-M. (2008). Tarinat teatterin taiteellisessa prosessissa [Stories in the artistic process of theatre making] (Unpublished doctoral dissertation). Acta Scenica 21. Scenic Art and Research. Helsinki: Theatre Academy.

Kress, G. \& van Leeuwen, T. (2001). Multimodal discourses: The modes and media of contemporary communication. London: Arnold.

Kunstbasert forskning (2014). Forskning: satsningsområder ved IKM. Retrieved March 26, 2014 from http://www.ntnu.no/ikm/kunstbasert-forskning 
Leavy, P. (2009). Method meets art: Arts-based research practice. New York \& London: The Guilford Press.

Nelson, R. (2013) Practice as research - Principles, protocols, pedagogies, resistances. Hampshire: Palgrave Macmillan.

Merleau-Ponty, M. (1962). The visible and the invisible. Evanston, IL.: Northwestern University Press.

Norwegian Artistic Research Programme (2014). Retrieved April 01, 2014 from http://artisticresearch.no/

PARIP 2001 - 2006. Practice as research in performance 2001-2006. Retrieved April 01, 2014 from http://www.bris.ac.uk/parip/

Pearce, W. B. (2004). The coordinated management of meaning (CMM). In B. G. (Ed.), Theorizing about communication and culture. Thousand Oaks, CA: Sage. Retrieved February 01, 2014 from http://www.pearceassociates.com/essays/cmm_seminar.pdf

Prendergast, M., \& Saxton, J. (Eds.) (2009). Applied theatre: International case studies and challenges for practice. Bristol: Intellect.

Rasmussen, B. (2012). Kunsten å forske med kunsten: Et blikk på kunnen ut fra praksis-teorirelasjonen. In B. Rasmussen \& R. Gürgens Gjærum (Eds.), Forestilling, framføring, forskning: metodologi i anvendt teaterforskning (pp. 23-49). Trondheim: Akademika forlag.

Rasmussen, B. (2014). The art of researching with art: Towards an ecological epistemology. Applied Theatre Research, 2(1), 21-32.

Riley, S. R., \& Hunter, L. (Eds.) (2009). Mapping landscapes for performance as research. Basingstoke: Palgrave Macmillan.

Rønning, B. (2011). Høyblokkas Minneforestilling. [The Tower Block Memorial Performance] Artsbased research project. Retrieved April 12, 2014 from http://www.hoyblokka.no/eng.php

SHARE (2014). Overview of publications and conferences about research in the arts. Retrieved March 31, 2014 from http://www.sharenetwork.eu/artistic-research-overview/bibliography

Smith, H., \& Dean, R. T. (Eds.) (2009). Practice-led research, research-led practice in the creative arts. Edinburgh: Edinburgh University Press.

Steigum, J. B. (2012). Et sprang i mørket: dramaleereren som regissør [A leap in darkness: Drama teacher as director] (Unpublished master's dissertation). Trondheim: NTNU.

Taylor, P. (Ed.) (1996). Researching drama and arts education: Paradigms and possibilities. London \& Washington, D. C.: The Falmer Press.

Thomson, P., \& Sefton-Green, J. (Eds.) (2011) Researching creative learning. London \& New York: Routledge.

van Manen, M. (1990). Researching lived experience. Human science for an action sensitive pedagogy. New York: State University of New York Press.

Vassenden, E. (2013). What is critical reflection? A question concerning artistic research, genre and the exercise of making narratives about one's own work. Norwegian Artistic Research Programme. Bergen: Bergen Academy of Art and Design. Retrieved April 01, 2014 from http://artisticresearch.no/wp-content/uploads/2012/09/What-is-critical-reflection.pdf

Wilson, M., \& van Ruiten, S. (Eds.) (2013). SHARE: Handbook for artistic research education. ELIA. Leiden: Leiden University Press. Retrieved March 31, 2014 from http://www.sharenetwork.eu/resources/share-handbook

Wiseth, H. (2011). Oppdrag Aquila: En undersøkelse av en dramatikers skapende prosess [Mission Aquila: A study of the creative process of dramatist] (Unpublished master's dissertation). Trondheim: NTNU.

Zipes, J. (2004). Speaking out: Storytelling and creative drama for children. New York \& London: Routledge. 